\title{
Social protection to combat hunger
}

To the Editor - COVID-19 and the measures governments have put in place to prevent its aggravation have triggered an economic recession that will increase poverty rates and hunger. In June, the International Monetary Fund projected a $4.9 \%$ decline in global economic growth compared to $2019^{1}$. A similar forecast has been generated under Ceres2030, a research project co-directed by the International Food Policy Research Institute, Cornell University and the International Institute for Sustainable Development that is calculating the cost of effective interventions to end hunger sustainably ${ }^{2}$. The estimate is that 95 million additional people, mostly from sub-Saharan Africa, will be living in extreme poverty by the end of the year ${ }^{3}$.

One of the first and most common policy responses to COVID-19 was to restrict the movement of people. For the approximately $85 \%$ of Africans who work in the informal sector, often living from day to day, the lockdown means that they are unable to put food on their families' tables ${ }^{4}$. Senegal's farmers and itinerant traders, for example, have been hit hard by the closing of markets, an overnight curfew and a ban on travel between regions that makes it difficult for them to sell their produce ${ }^{5}$. While initially the Senegalese government did not face major political opposition for its handling of the pandemic, recent unrest in Dakar and Touba has highlighted a dilemma shared by many countries in the region: measures taken to protect citizens' health are damaging the livelihoods of millions who work in the informal sector, creating economic distress and adding to political tensions. Falling ill or dying from COVID19 are not the only risks faced by the population.

Governments around the world have protected short-term income and purchasing power however they could, hoping to contain social upheaval and the number of decimated livelihoods ${ }^{6}$. Togo, for example, has recently announced the launch of an unconditional cash transfer scheme designed to support all Togolese informal workers whose incomes are disrupted by COVID- $19^{6}$.

Efforts like these, essential in times of crisis, are forms of social protection - that is, public or private initiatives that aid the poor and protect the vulnerable against livelihood risks. Social assistance (that is, the transfer of resources either as cash or in-kind) is a form of social protection that restores some level of predictability and protects vulnerable households from hunger. By preventing the destocking of productive assets through distress sales, social assistance also protects investments that could contribute to food security, increased productivity and income, and more sustainable farming systems. Protection against hunger and prevention of asset depletion constitute the first two objectives of social protection.

The pandemic has laid bare the precariousness of the livelihoods of millions of people who have been unable to benefit from the opportunities created by two decades of economic growth in Africa? Evidence reveals that the greater the inequality in the distribution of assets such as land, water, capital, finance, education and health, the more difficult it is for the poor to participate in economic growth processes $^{8}$. Although responses to COVID19 in the form of resource transfers help prevent and manage situations that adversely affect people's well-being, they do not help households overcome their pre-existing state of vulnerability. Thus, as many countries start reducing social distancing measures related to COVID-19, they should also move towards a more sustainable set of policies to eradicate deep-rooted poverty and hunger, and pay greater attention to the third objective of social protection: the promotion of livelihoods.

Social protection favours increased productivity and higher incomes among small-scale food producers through several channels ${ }^{9}$. First, social protection payments (for example, unconditional cash transfers) reduce liquidity constraints, thus freeing household income for productive spending such as the purchase of agricultural inputs. When regular and predictable, these payments can facilitate small-scale savings or investment by acting as a collateral, enabling the beneficiaries to access credit. Second, social protection instruments can increase a household's tolerance to risk by augmenting household wealth. With more financial reserves, household members tend to invest in their productive capacity by, for example, buying new machinery or experimenting with novel seed varieties. Third, social protection instruments may have a positive effect on food and nutrition security, which in turn will enhance labour productivity.

The positive effects of social protection programmes are not a given. In Kenya, a recent model-based impact assessment showed that rural households receiving a cash transfer were benefiting from the increased income; the target population were households living in the greatest poverty ${ }^{10}$. But the recipients were not necessarily able to take advantage of the increased demand for goods and services that resulted from the rise in income within the community associated with the social protection programme because they lacked the necessary assets and labour hours to expand their activities. If social protection programmes were adequately designed to lift recipients out of poverty, indirect income gains for programme beneficiaries could be much larger. One way to do this is by supplementing cash or in-kind payments with training measures; a more skilled workforce would be better positioned to quickly expand its activities and increase productivity levels in response to a rise in demand, and eventually graduate from social protection programmes.

The so-called cash plus, livelihood or graduation programmes combine regular cash transfers with measures to encourage behavioural changes and/or address supply constraints. Ethiopia's Productive Safety Net Programme, for example, has sought to promote agricultural production and productivity. Essentially, the programme combines unconditional cash or in-kind transfers to those who cannot supply labour with transfers that are conditional on supplying labour to public works. In addition, the programme includes livelihood development packages designed to build a pool of assets essential for sustained income generation and graduation from the programme. This mix of interventions has led to a reduction of the hunger period experienced by households every year by one-third (or 1.29 months per year on average $)^{11}$. Yet, the programme has not enabled the graduation of its own beneficiaries, without which it may soon become too heavy of a fiscal burden to the national government. Ethiopia's social protection programme demonstrates that desirable synergies exist, and the integration of social protection with measures to increase agricultural productivity holds the potential for making significant inroads towards the eradication of hunger.

Social protection schemes need to be multi-sectoral, broadened and institutionalized to be sufficiently redistributive and buffer the effects of 
economic slowdowns and downturns on food security. In particular, the engagement of agriculture ministries in the design and implementation of social protection programmes can maximize the impact of social sector expenditures on agricultural productivity - a powerful sweet spot for governments in their objective of achieving long-term poverty reduction and hunger eradication.

Fleur Wouterse', Sophia Murphy ${ }^{2}$ and Jaron Porciello (iD) 3 的

${ }^{1}$ International Food Policy Research Institute (IFPRI), Washington, DC, USA. ${ }^{2}$ International Institute for Sustainable Development (IISD), Winnipeg, Manitoba, Canada. ${ }^{3}$ Cornell University, Department of Global Development, Ithaca, NY, USA.

凶e-mail: jat264@cornell.edu

Published online: 15 September 2020

https://doi.org/10.1038/s43016-020-00144-1

References

1. World Economic Outlook Update, June 2020: A Crisis Like No Other, An Uncertain Recovery (IMF, 2020); https://go.nature. com/34bvYSG

2. Porciello, J., Laborde, D., Murphy, S. \& Smaller, C. A Global Value Chain of Knowledge to End Hunger Sustainably (IISD, 2020); https://hdl.handle.net/1813/70166

3. Laborde, D., Bizikova, L., Lallemant, T. \& Smaller, C. Ending Hunger: What Would It Cost? (IISD, 2016).

4. Women and Men in the Informal Economy: A Statistical Picture 3rd edn (ILO, 2018); https://go.nature.com/3kTr8iQ

5. Senegal to ease some coronavirus curbs after protests escalate. Al Jazeera (4 June 2020); https://go.nature.com/ $3 \mathrm{~h} 8 \mathrm{fGOa}$
6. Gentilini, U., Almenfi, M., Orton, I. \& Dale, P. Social Protection and Jobs Responses to COVID-19: A Real-Time Review of Country Measures (World Bank, 2020); http://hdl.handle.net/10986/33635

7. McKay, A. J. Afr. Econ. 22, i49-i76 (2013).

8. The State of Food Security and Nutrition in the World 2019: Safeguarding Against Economic Slowdowns and Downturns (FAO, 2019).

9. Wouterse, F. S. \& Taffesse, A. S. Boosting Growth to End Hunger by 2025: The Role of Social Protection (IFPRI, 2018).

10. Thome, K., Filipski, M., Kagin, J., Taylor, J. E. \& Davis, B. Am. J. Agric. Econ. 95, 1338-1344 (2013).

11. Berhane, G., Gilligan, D. O., Hoddinott, J., Kumar, N. \& Taffesse, A. S. Econ. Dev. Cult. Change 63, 1-26 (2014).

Author contributions

F.W. drafted the manuscript. S.M. and J.P. provided critical revision of the manuscript. All authors approved the final version of the manuscript.

Competing interests

The authors declare no competing interests. 